\title{
Perancangan E-Payment System pada E-Wallet Menggunakan Kode QR Berbasis Android
}

\section{E-Payment System Design in E-Wallet Using Android-Based on QR Codes}

\author{
A Mulyana ${ }^{1 *}$, H Wijaya $^{2}$ \\ 1,2) Program Studi Sistem Komputer, Fakultas Teknik dan Ilmu Komputer, Universitas Komputer Indonesia \\ Jl. Dipati Ukur No. 112 - 116, Bandung, Indonesia 40132 \\ e-mail: agus.mulyana@email.unikom.ac.id
}

\begin{abstract}
An electronic money payment system (e-payment) is a non-cash payment method that is stored in a server based on (e-wallet) or chip based (e-money). With the aim, it can facilitate users when making payment or transfer transactions. Currently in Indonesia the use of e-wallet is still smaller than e-money users, because the method of using e-money isconsidered easier and more flexible. The variety of payment transaction methods and transfer features that are only to e-wallet users, make e-money more popular with the Indonesian people. To meet these needs, therefore the need for Electronic DataCapture that can provide options for users to transact using several methods, namely using fingerprints, RFID cards, or Android applications.
\end{abstract}

Keywords - e-Payment, e-Wallet, e-Money, QR, RFID, Android

\begin{abstract}
ABSTRAK - Sistem pembayaran uang elektronik (e-payment) adalah metode alat pembayaran nontunai yang disimpan di dalam server based (e-wallet) atau chip based (e-money). Dengan tujuan, dapat mempermudah penguna saat melakukan transaksi pembayaran atau transfer. Saat ini di Indonesia penguna e-wallet masih lebih kecil dibandingkan pengguna e-money, dikarenakan metode penggunaan e-money dianggap lebih mudah dan fleksibel. Beragamnya metode transaksi pembayaran serta fitur transfer yang hanya ke sesama pengguna e-wallet, membuat emoney lebih digemari masyarakat Indonesia. Untuk memenuhi kebutuhan tersebut maka dari itu perlunya Electronic Data Capture yang dapat memberikan pilihan bagi pengguna untuk bertransaksi menggunakan beberapa metode, yaitu menggunakan sidik jari, kartu rfid, atau aplikasi android.
\end{abstract}

Kata Kunci - e-Payment, e-Wallet, e-Money, QR, RFID, Android

\section{Pendahuluan}

Sistem pembayaran uang elektronik (e-payment) tidak dipungkiri menjadi salah satu solusi media pembayaran atau penyimpanan dana sementara. Saat ini, e-payment sudah berkembang dan semakin lazim dipakai oleh masyarakat Indonesia baik yang berupa kartu (e-money) atau berbasiskan aplikasi (ewallet)[1]. Kenyataan ini memperlihatkan bahwa jasa pembayaran e-payment yang dilakukan Bank maupun lembaga selain Bank (LSB), baik dalam proses pengiriman dana, penyelenggara kliring maupun sistem penyelesaian akhir (sattlement) sudah tersedia dan dapat berlangsung di Indonesia.

Menurut BI (Bank Indonesia) proses transaksi tunai sedikitnya Rp. 174,3 triliun/hari, sedangkan $e$ - payment Rp. 8,8 triliun/hari baik itu yang dilakukan oleh Bank maupun LSB [2]. Hal ini membuktikan bahwa walaupun e-payment sudah berkembang dan semakin lazim dipakai oleh masyarakat akan tetapi rasio penggunanya masih lebih kecil dibandingkan dengan pengguna tunai. Mengapa, Hal ini diakibatkan dari kurangnya kenyamaan dan keamanan e-money baik itu debit atau kredit, contohnya ketika kartu rusak, hilang dan lain sebagainya.

Ketika kartu hilang maka pengguna harus segera melakukan pemblokiran untuk mengurangi resiko pencurian. Saat ini, proses pemblokiran hanya dapat dilakukan dengan cara datang langsung ke instansi terkait atau melalui telpon. Akan tetapi, ketika pengguna akan membuat kartunya kembali 
pengguna harus menyediakan dokumen ulang bahkan surat kehilangan dari kepolisian dan lain sebagainya [3]. Hal ini yang membuat pengguna $e$ money enggan untuk membuat kartunya kembali.

Maka dari itu penulis berupaya membuat Epayment System yang dapat memberikan kemudahan bertransaksi dengan memiliki 3 metode yaitu menggunakan Sidik Jari, RFID dan QR Code serta pengelolaan keuangan menggunakan aplikasi Android

\section{METODE DAN BAHAN}

\subsection{Metode Penelitian}

Metode yang dilakukan untuk membuat sistem ini yaitu:

1. Studi Literatur

Metode studi literatur dilakukan dengan cara mempelajari sumber referensi yang berhubungan dengan penelitian yang dilakukan, diantaranya melalui buku, jurnal dan internet.

2. Observasi (Survei lapangan)

Pengumpulan data lapangan, untuk mengetahui apakah sudah terdapat alat sejenis atau belum. Dan jika sudah ada, apa perbedaan dengan alat yang dibuat oleh penulis.

3. Perancangan

Metode ini meliputi perancangan software dengan menggunakan Android Nougat dan database yang akan digunakan pada sistem ini.

4. Pengujian

Pengujian dilakukan secara modular dan keseluruhan pada sistem yang telah selesai dibuat. Pengujian dilakukan untuk memenuhi apakah sistem sudah berfungsi dengan baik atau belum.

5. Wawancara

Wawancara dilakukan untuk mendapat saran dan komentar dari pihak yang berhubungan dengan sistem ini yaitu masyarakat.

6. Dokumentasi

Menyusun laporan dan pembuatan dokumen penelitian.

\subsection{E-Payment System}

E-payment adalah sistem pembayaran yang menggunakan media internet sebagai komunikasi. Banyak perusahaan yang menyediakan pihak penjual dan pembeli dengan memberikan jaminan keamanan transaksi elektronik. Untuk menjamin keamanan transaksi tersebut, perusahaan yang menjadi perantara akan bekerja sama dengan sejumlah lembaga perbankan untuk mulai memfasilitasi e-payment secara aman, cepat dan praktis[2].

\subsection{E-Money}

E-money adalah alat pembayaran digital atau alat pembayaran yang menggunakan media elektronik berupa chip. Pada umumnya e-Money berupa kartu baik itu debit maupun kredit. Terdapat beberapa $e$ Money chip basedyang saat ini ada di pasar yaitu Flazz BCA, E-Money Mandiri, Brizzi BRI, Tap Cash BNI, Blink BTN, Mega Cash, Nobu E-Money, JakCard Bank DKI dan Skye Mobile Money terbitan Skye Sab Indonesia

\subsection{E-wallet}

E-Wallet atau dompet elektronik adalah alat pembayaran digital atau alat pembayaran digital yang menggunakan media elektronik berupa server based. Pada umumnya $e$-Wallet berupa aplikasi yang berbasis di server dan dalam proses pemakaiannya memerlukan sebuah koneksi terlebih dulu dengan penerbitnya. Terdapat beberapa $e$-Wallet yang saat ini ada di pasar yaitu T-Cash Telkomsel, XL Tunai, Rekening Ponsel CIMB Niaga, BBM Money Permata Bank, DOKU, dan lain sebagainya [3].

\subsection{Kode QR}

Kode QR adalah suatu jenis kode matriks atau kode batang dua dimensi yang dikembangkan oleh Denso Wave, sebuah divisi Denso Corporation yang merupakan sebuah perusahaan Jepang dan dipublikasikan pada tahun 1994 dengan fungsionalitas utama yaitu dapat dengan mudah dibaca oleh pemindai QR merupakan singkatan dari quick response atau respons cepat, yang sesuai dengan tujuannya adalah untuk menyampaikan informasi dengan cepat dan mendapatkan respons yang cepat pula. Berbeda dengan kode batang, yang hanya menyimpan informasi secara horizontal, kode QR mampu menyimpan informasi secara horizontal dan vertikal, oleh karena itu secara otomatis kode QR dapat menampung informasi yang lebih banyak daripada kode batang[4,5,6]. Gambar 1 merupakan tampilan kode QR.

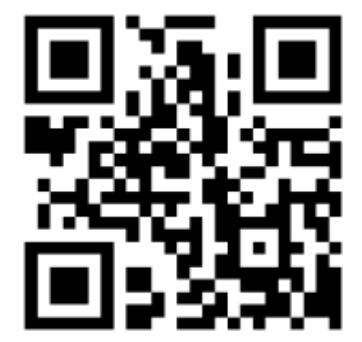

Gambar 1. Kode QR 


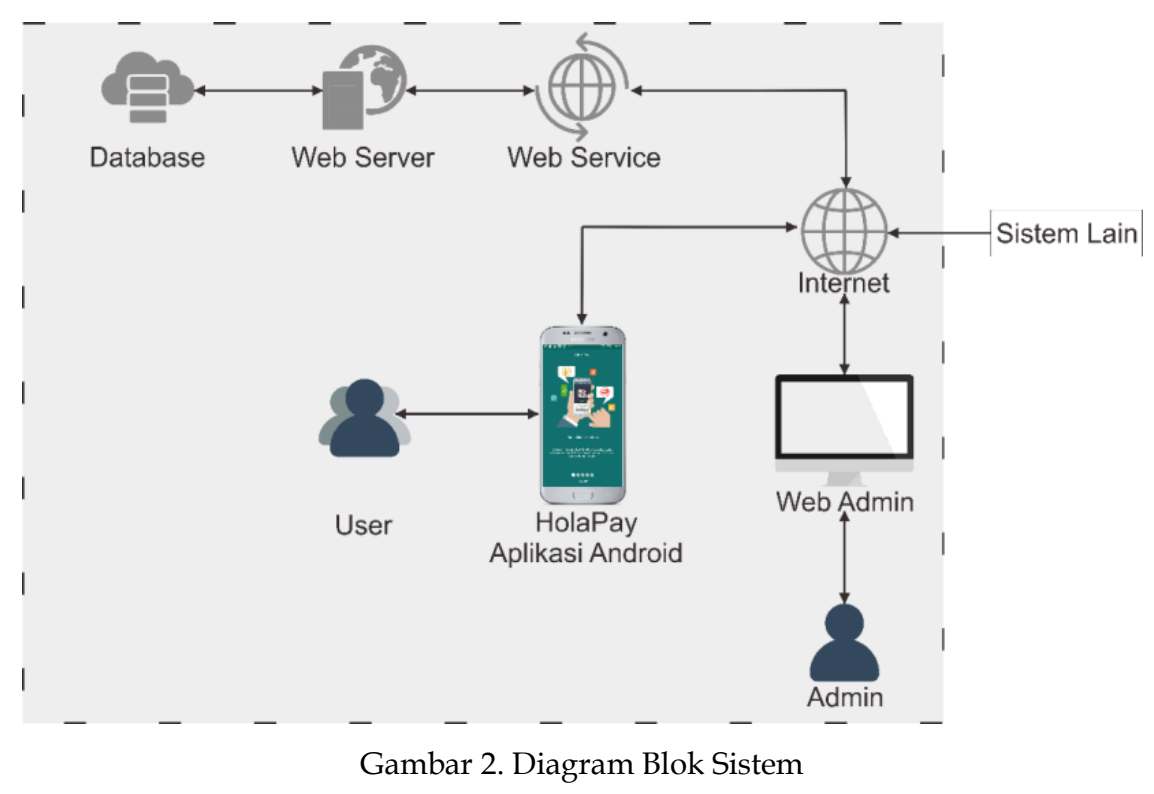

\subsection{Diagram Blok}

Pada Gambar 2 merupakan diagram blok sistem yang menjelaskan antar sub sistem, didalam blok terdapat sistem yang akan di buat dan sistem lain terdapat diluarnnya.

Keterangan diagram blok sistem pada Gambar 2 diterangkan pada Tabel 1.

Tabel 1. Keterangan Diagram Blok Sistem

\begin{tabular}{ll}
\hline Blok & \multicolumn{1}{c}{ Deskripsi } \\
\hline Admin & Pada bagian admin dapat melakukan \\
& beberapa proses diantaranya: melihat \\
& data pengguna yang daftar untuk di \\
& verifikasi, melihat data transaksi untuk di \\
& eksekusi, melihat data transfer untuk di \\
& eksekusi, melihat data pencairan dana \\
& untuk di eksekusi, dan melihat data topup \\
& saldo untuk di eksekusi. \\
& Pada bagian user dapat melakukan \\
& beberapa proses diantaranya: dapat \\
User & mendaftar sebelum melakukan proses \\
& transaksi, dapat memverifikasi email \\
& sebelum dapat melakukan login, dapat \\
& melakukan transaksi pembayaran \\
& menggunakan kode QR, dapat \\
& mentransfer saldo aplikasi ke akun \\
& sesama pengguna Hola Pay/ bank, dapat \\
& melakukan pencairan dana dari saldo \\
& aplikasi, dapat membut RFID yang \\
diverifikasi melalui kode QR sebgai opsi \\
lain pembayaran, dapat memblokir RFID \\
yang hilang, dan dapat mengisi saldo. \\
Sebagai Front-End aplikasi bagi pembeli \\
berbasiskan smartphoneAndroid. \\
Sebagai Back-Endaplikasi bagi admin \\
berbasikan web. \\
Sebagai media utama penghubung pada \\
sistem. Padmin
\end{tabular}

\begin{tabular}{ll}
\hline Web & Berfungsi untuk mejembatani hubungan \\
Service & antara client dan server (web server). \\
PC Admin & Sebagai perangkat admin untuk dapat \\
& mengakses halaman admin pada web \\
Database & Berfungsi menyediakan layanan \\
Server & penyimpanan data. \\
\hline
\end{tabular}

\subsection{Perancangan Software Aplikasi Android}

Aplikasi Android hanya dipergunakan oleh user untuk melakukan transaksi, transfer, tarik dana, top up saldo, pembelian pulsa, melihat riwayat, membuat kartu RFID dan memblokir kartu RFID. Gambar 3 sampai Gambar 6 merupakan tampilan aplikasi Android yang dibuat.

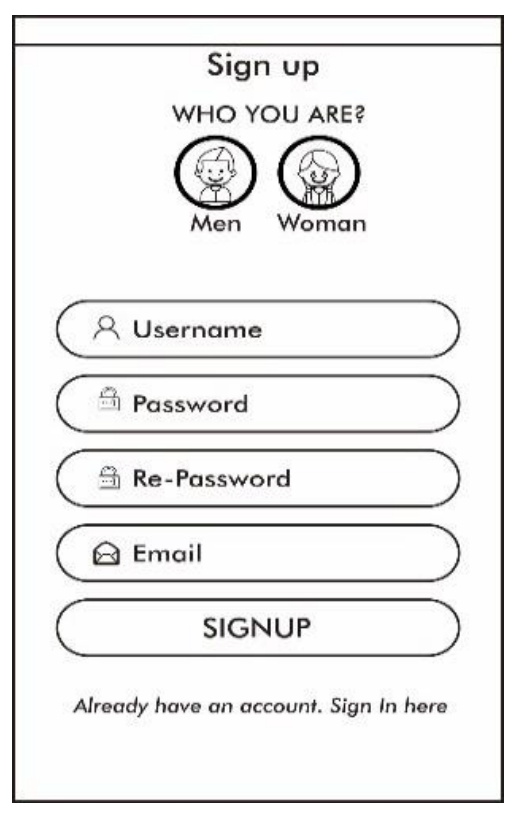

Gambar 3. Sign-Up 


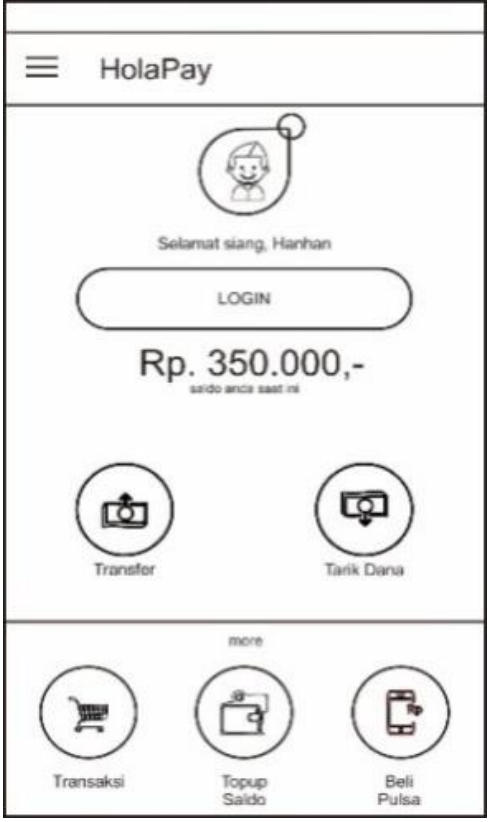

Gambar 4. Home

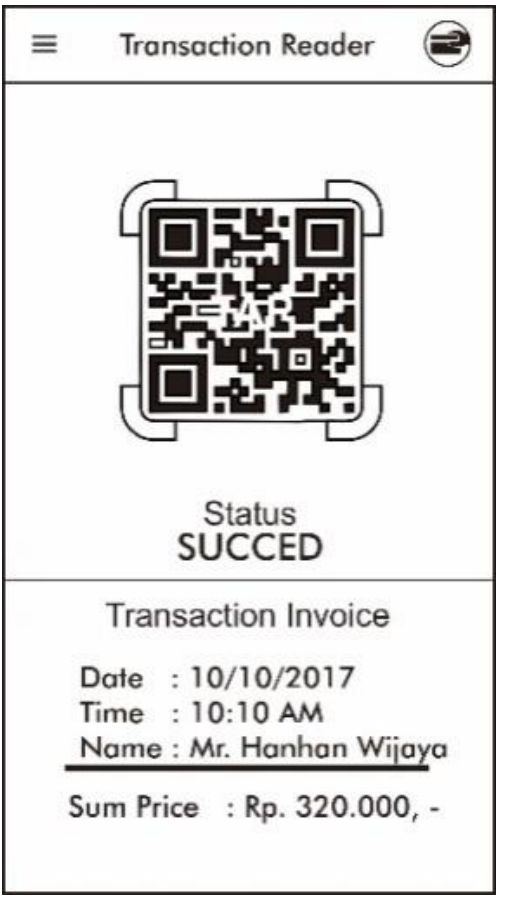

Gambar 5. Transaction

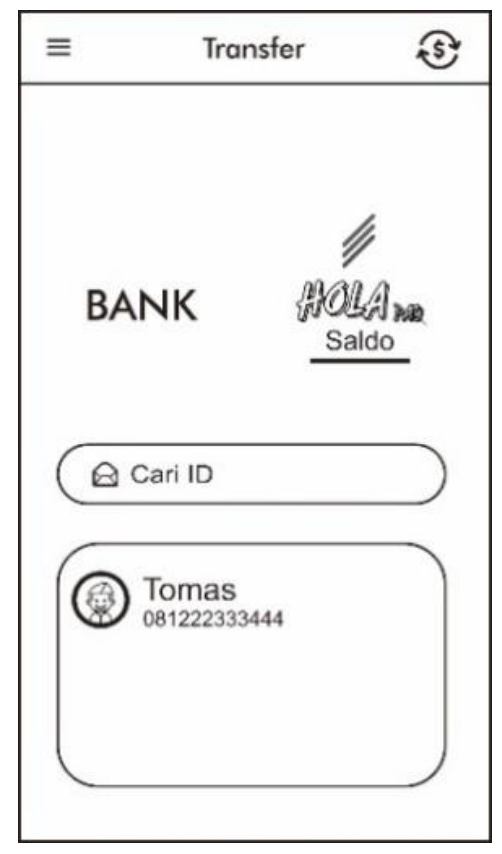

Gambar 6. Transfer

Deskripsi Gambar :

1. Pengguna hanya dapat mendaftarkan akun di satu username dan alamat email saja, sehingga menghindari adanya persamaan akun antara pengguna seperti pada gambar Gambar 3.

2. Beberapa menu seperti Saldo, Transaksi, Transfer, Pencairan Dana, Topup saldo, dan historytertera di halaman utama sedangkan untuk lainnya akan ditampilkan pada list slide menu seperti pada Gambar 4.

3. Menu Transaction Reader merupakan menu Transaksi bagi pengguna melalui Kode QR dimana nantinya pengguna akan dimintai untuk menscan Kode QR dan akan tampil data berupa invoiceseperti pada Gambar 5 .

4. Menu Transfer merupakan menu yang dapat memindahkan saldo aplikasi ke sesama pengguna aplikasi, maupun menjadikannya saldo nominal ke rekening bank seperti pada Gambar 7.

\subsection{Perancangan Software WebAdmin}

Webadmin hanya dipergunakan oleh admin untuk mengeksekusi data user baik itu tarik dana maupun topusp saldo, selain itu admin juga dapat melihat data transaksi maupun transfer data seluruh user. Tampilan dari webadmin dan dashboard dapat dilihat pada Gambar 7 dan Gambar 8. 


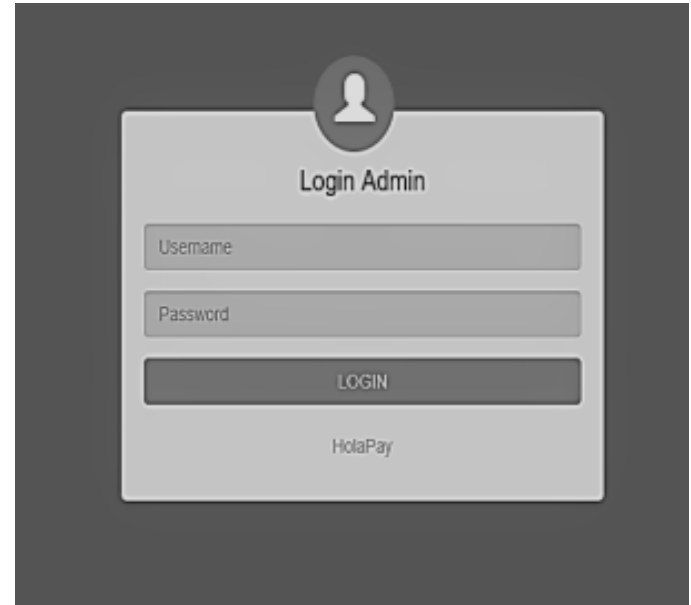

Gambar 7. Halaman Login Admin
Jika persamaan 1 dinotasikan dengan notasi sigma, maka persamaan 1 menjadi persamaan 2 berikut :

$\overline{\mathrm{t}}=\frac{\sum_{t=1}^{n} t}{n}$

Sehingga rata-rata respon time system aplikasi dalam mengambil dan mengeksekusi data ke web server $1.85 \mathrm{~s}$ dan respon time system web admin dalam mengambil dan mengeksekusi data ke web server sebesar $1.75 \mathrm{~s}$. dari kedua nilai rata-rata respon sistem tersebut dapat dikategorikan HolaPay dapat menjalakan sistem dengan waktu yang cepat, sehingga user tidak perlu menunggu lama dalam penggunaan HolaPay.

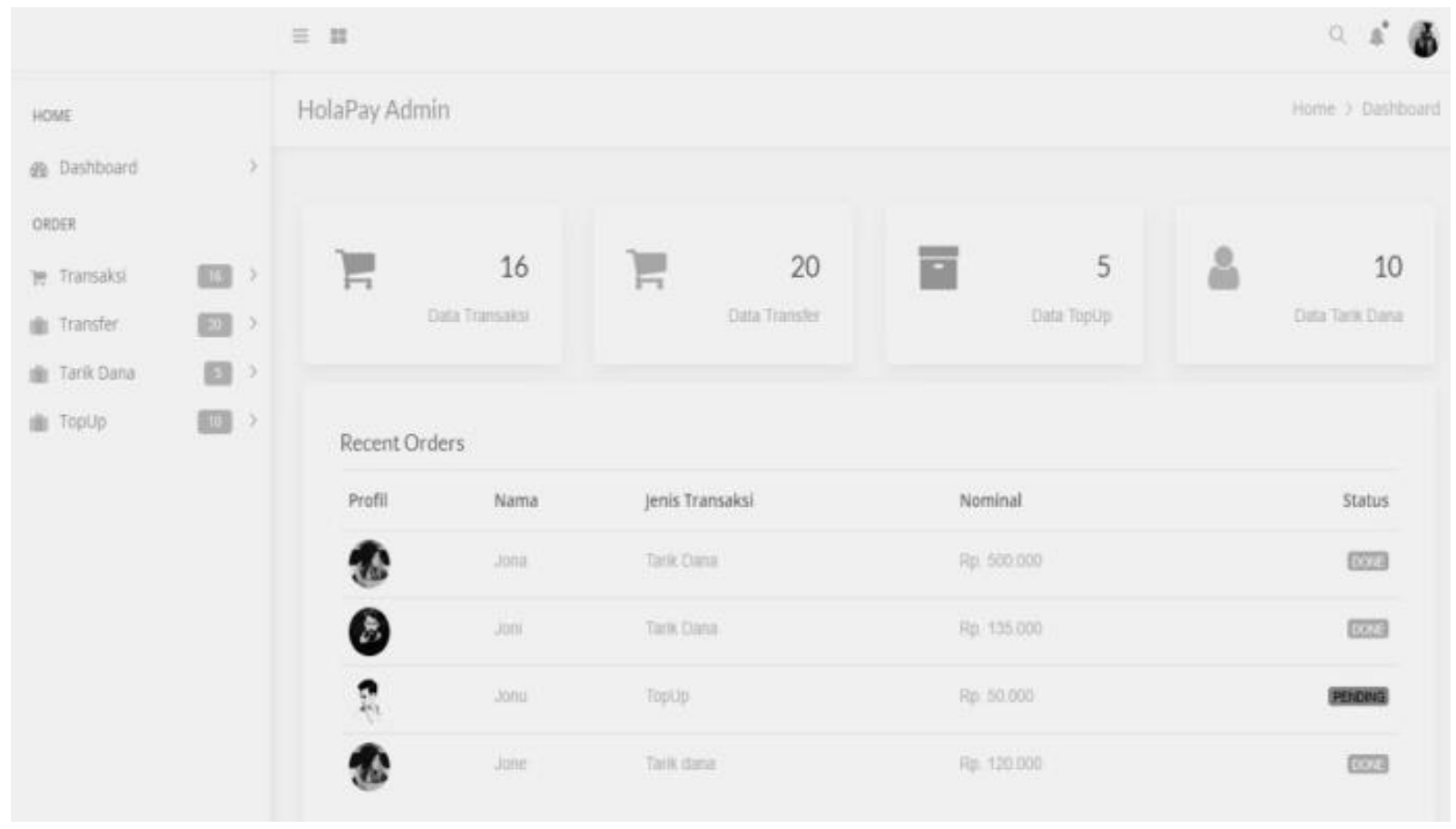

Gambar 8. Halaman Dashboard Admin

\section{HASIL DAN PEMBAHASAN}

Respon time system pada konten aplikasi ini, dilakukan sebanyak 10 kali percobaan dari t1 sampait 10 untuk mengetahui seberapa cepat sistem dapat mengambil dan mengeksekusi data dari aplikasi ke web server.

Rata-rata waktu $(\overline{\mathrm{t}})$ didapatkan menggunakan pencarian rata-rata hitung (aritmatik) dengan menjumlahkan seluruh nilai data (t) kemudian dibagi dengan jumlah sampel tersebut. Rumus perhitungan rata-rata dapat dilihat dari persamaan 1 :

$\overline{\mathrm{t}}=\frac{1}{n}=(\mathrm{t} 1+\mathrm{t} 2+\ldots . . \mathrm{tn})$
Selain memperhatikan rata-rata respon time system, ada beberapa criteria lain yang perlu diperhatikan, antara lain kemudahan dalam penggunaan sistem oleh masyarakat. Oleh karena itu perlu dilakukan menyebarkan kuisioner yang dihitung menggunakan skala likert untuk menilai kriteria user friendly, Respon Time System, Design, Benefits, etc (Kapasitas). Kuisioner ini dilakukan random responden dengan jumlah 10 responden.

Keterangan didapatkan dari persamaan berikut :

$$
\text { Ket }=\frac{\sum_{r=1}^{n} \text { skor }}{\text { max jumlah skor }} \times 100 \%
$$

Sehingga didapatkan kesimpulan range keterangan sebagai berikut: 
Tidak setuju $=0 \%-33,3 \%$

Netral $=33,3 \%-66,6 \%$

Setuju $=66,6 \%-100 \%$

dan hasil kuisioner dapat dilihat pada Tabel 2.

Tabel 2. Perhitungan Persentase Kuisioner HolaPay

\begin{tabular}{lcl}
\hline Pertanyaan & $\begin{array}{l}\text { Nilai Persentase } \\
(\%)\end{array}$ & Keterangan \\
\hline User Friendly & 96,6 & Setuju \\
$\begin{array}{l}\text { Respon Time } \\
\text { System }\end{array}$ & 90 & Setuju \\
Design & 96.6 & Setuju \\
Benefits & 86.6 & Setuju \\
$\begin{array}{l}\text { Etc } \\
\text { (Kapasitas) }\end{array}$ & 90 & Setuju \\
\hline
\end{tabular}

Dari hasil kuisioner untuk kriteria user friendly mendapatkan 96,6 \% dapat dikategorikan bahwa HolaPay aplikasi yang mudah digunakan dan dimengerti, kategori respon time system mendapatkan 93,3\% yang dapat diartikan bahwa HolaPay dapar menjalakan sistem dengan waktu yang cepat, kategori design mendapatkan persentase sebesar 96,6 yang artinya Holapay tampilannya sangat menarik, kekinian meliputi perpaduan warna, text dan icon yang digunakan, kriteria Benefits mendapatkan persentasi $86.6 \%$ yang artinya HolaPay dapat menjadi solusi E-wallet System yang masih meliputi mempermudah transaksi, transfer dana, tarik dana, topup saldo, dll. Terakhir kapasitas memori yang digunakan mendapatkan persentase 90\% yaitu HolaPay merupakan aplikasi yang ringan tidak memakan banyak ruang memori.

\section{KeSIMPULAN}

Berdasarkan pengamatan dan data yang telah didapatkan dari beberapa pengujian, "E-Payment System Menggunakan Kode QR Berbasis Android" menghasilkan beberapa kesimpulan sebagai berikut :

1. Berdasarkan hasil pengujian alpha pada aplikasi, didapatkan kesimpulan sebagai berikut :

- Uji antarmuka

Fungsional parameter konten yang tersedia pada aplikasi, mampu menampilkan dan berfungsi sesuai dengan apa yang dirancang.

- Uji compatibility

Aplikasi dapat menampilkan dan berfungsi \} di setiap parameter konten yang tersedia di berbagai perangkat smartphoneAndroid dengan minimal versi Android 4.2.2 (Jelly
Bean) dan dengan minimal ukuran layar 5.0 inch.

- Uji respon time system

Dengan menggunakan provider 3 sebagai jaringan, aplikasi mampu mengambil dan mengeksekusi data dari aplikasi ke web server ataupun sebaliknya dengan waktu tidak lebih dari 5 detik, sehingga aplikasi dapat dikatakan respon time system.

- Uji pengiriman gambar

Dengan menggunakan provider 3 sebagai jaringan, aplikasi mampu mengirim gambar dengan format jpg, jpeg dan png sebagai bukti pembayaran dengan size maksimum tidak lebih dari 2,1 MB.

- Uji pembacaan kode QR

Sistem mampu membaca dan mengenali kode QR denganvalue yang terdaptar di data basesistem.

2. Berdasarkan hasil pengujian alpha pada web, didapatkan kesimpulan sebagai berikut :

- Uji antarmuka

Fungsional parameter konten yang tersedia pada web, mampu menampilkan dan berfungsi sesuai dengan apa yang dirancang.

- Uji respon time system

Dengan menggunakan provider 3 sebagai jaringan, web admin mampu mengambil dan mengeksekusi data dari webadmin ke web server ataupun sebaliknya dengan waktu tidak lebih dari 5 detik, sehingga web admin dapat dikatakan respon time system.

3. Berdasarkan hasil pengujian beta pada aplikasi, didapatkan kesimpulan aplikasi HolaPay (EPayment SystemPada E-Wallet Menggunakan Kode QR Berbasis Android) telah memenuhi kriteria.

\section{UCAPAN TERIMA KASIH}

Penulis mengucapkan terimakasih yang sebesarbesarnya kepada pihak-pihak terkait yang telah membantu dalam penelitian dan juga dalam penulisan jurnal ini. Mahasiswa yang ikut ambil bagian dalam penyelesaian penelitian.

\section{DAFTAR PUSTAKA}

[1] R. Ibrahim and S. Y. Yen, "Formalization Of The Data Flow Diagram Rules For Consistency Check," International Journal Of Software Engineering \& Applications, vol. 1, p. 96, 2010.

[2] "Kekurangan Tunai vs Keuntungan Nontunai," 16 Februari 2017. [Online]. Available: http://www.nontunai.com/kekurangan-tunaivs-keuntungan-nontunai/. [Accessed 3 Agustus 2018]. 
[3] "PPG DALAM JABATAN," PPG SPADA RISTEKDIKTI, [Online]. Available: ppg.spada.ristekdikti.go.id/master/mod/reso urce/view.php?id=7942. [Accessed 18 2018].

[4] www.halomoney.co.id [Online]// halomoney Februari 18 2018. -

[5] https://www.halomoney.co.id/blog/mengena 1-perbedaan-uang-elektronik-e-Money-dan-eWallet.

[6] www.qrpay.com [Online] // qrpay - Oktober 13, 2017. - http://www.qrpay.com/ indonesia/Contents/Default.aspx.

[7] ww.pymnts.com [Online] // pymnts - Oktober 13 , 2017. hhttps://www.pymnts.com/news/internation al/2016/india-government-standard-qr-codeepayments-indian-notes.

[8] M.KOM Mochamad Fajar W. Komputer Aplikasi. Dokumen. 